\section{$\underset{\substack{\text { hommes } \\ \text { \& migrations }}}{ }$}

\section{Hommes \& migrations}

Revue française de référence sur les dynamiques

migratoires

$1331 \mid 2020$

Femmes engagées

\title{
Maylis Adhémar, Bénie soit Sixtine
}

Paris, Julliard, 2020, 298 p., $19 €$

\section{Mustapha Harzoune}

\section{(2) OpenEdition}

\section{Journals}

\section{Édition électronique}

URL : https://journals.openedition.org/hommesmigrations/11886

DOI : 10.4000/hommesmigrations. 11886

ISSN : 2262-3353

\section{Éditeur}

Musée national de l'histoire de l'immigration

\section{Édition imprimée}

Date de publication : 17 novembre 2020

Pagination : 189

ISBN : 978-2-919040-52-0

ISSN : $1142-852 X$

\section{Référence électronique}

Mustapha Harzoune, "Maylis Adhémar, Bénie soit Sixtine », Hommes \& migrations [En ligne], 1331 |

2020, mis en ligne le 01 novembre 2020, consulté le 06 janvier 2023. URL : http://

journals.openedition.org/hommesmigrations/11886; DOI : https://doi.org/10.4000/

hommesmigrations. 11886 


\section{Bénie soit Sixtine}

Maylis Adhémar, Paris, Julliard, 2020, 298 p., $19 €$

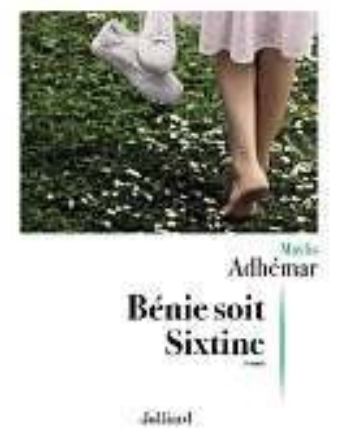

Un entre-soi de tranchée, la religion comme unique objet de 
distinction identitaire, des génuflexions à gogo et des prières à tire larigot, des femmes tout en domesticité et vouées à procréer, à la chaîne et des hommes de préférence - histoire de renforcer la soldatesque et de glorifier les martyrs d'une guerre sainte contre les «pédales et parasites», les mariages mixtes, les étrangers, les mécréants, les dépravés et les sans dieu... et un paradis pour justifier les pires crimes! Ces «frères et sœurs » en humanité condamnent

l'avortement, rejettent les corps, à commencer par celui des femmes, sacralisent la virginité - «le plaisir sexuel féminin est une invention»-, multiplient les sacrifices en rédemption des pêchés, glorifient mère, famille, lignée, pédigrée et pureté.

Pour ce premier roman, Maylis Adhémar brosse des descriptions de première main, dissèque le quotidien et les méninges de ces «fous de Dieu» partis en guerre contre un monde apostat. Qui sont-ils? Des séparatistes islamiques? Que nenni! Nuls mahométans djellabalisés et enturbannés, point de voiles ni de mimines gantées et intouchables. Non! Mais des mocassins en cuir, des mantilles et des jupes droites ajustées en dessous du genou, des pulls jetés sur l'épaule, des coupes militaires et des chignons. Ces «djihadistes» en mocassins s'entraînent au Puy du Fou, castagnent contre les «dégénérés» et meurent pour LA France éternelle, pure et débarrassée des «bamboulas», des Juifs et autres «Arabes». Maylis Adhémar dévoile avec une rare puissance l'univers, l'idéologie, les croyances et les rituels des membres d'une congrégation catholique intégriste plutôt frappadingues! Pour la Congrégation des Frères et Sœurs de la Croix, "le trône de Saint Pierre est vide», et pour défendre la fille aînée de l’Église, elle dispose d'une milice, prête à en découdre contre tout ce qui n'est pas eux.

Sixtine vient d'épouser PierreLouis Sue de La Garde, membre éminent de ladite milice. Elle a beau être une catho fervente, par sa mère Muriel éduquée dans le strict respect du Christ et de l'Église, elle ignore encore où elle vient de mettre les pieds.

Elle, dont les sens furent éveillés par une première et chaste expérience charnelle, attend avec impatience le licite «droit à l'union charnelle» de la nuit de noce. Le feu qui lui brûle les entrailles sera, et pour longtemps, éteint en quelques secondes par son croisé de mari, avec tout de même bénédiction, avant et après, le devoir accompli. Un «soyez féconds et multipliez-vous! » appliqué à la lettre. Tout est magistralement rendu par l'auteure: la mécanique froide du geste, les attentes, la déception et les doutes de la jeune épousée. Il faut lire ces pages! En cinq semaines, Sixtine subira à quatre reprises ce «devoir conjugal». Point trop n'en faut... juste de quoi enfanter un «petit croisé». L'amour chez les intégristes!

Bien sûr, Sixtine est frustrée, déprime, est seule dans cette famille de «gros malades». Ne trouve ni place ni mot à dire: un objet juste bon à procréer, entre les mains du mari et de la bellemère. Dégringolade! Timidement d'abord, elle se rebiffe. Sans le savoir, elle s'aventure sur le long chemin de son émancipation. Un chemin de souffrances. De culpabilité. De doutes. Et de prières, car Sixtine est croyante. Elle fuit, quitte mère et belle-mère, part avec son enfant: une évasion vers un inconnu fait de "païens» ou de réfugiés syriens - «Peut-elle aider ces réfugiés sans trahir la France?». Un «autre monde». Celui de la liberté. Peut-être.

Entre la chronique de cette union hors norme, se glissent de vieilles lettres adressées par une certaine Erika à Muriel. Ainsi, le passé frappe à la porte du présent. La généalogie, comme une source trop longtemps obstruée, s'en vient rejoindre et grossir le courant de la vie. On n'échappe pas à des origines qu'on a voulu enfermer dans la nuit du refoulement.

Le récit, dense et souvent intense, est truffé de rebondissements, de scènes fortes ou à se tordre (dialogue entre la catho et une gaucho pur sucre, etc.). Sixtine a choisi de prénommer son fils Adam, comme une transgression, un commencement. Bienvenue dans le monde des humains.

M. $\mathrm{H}$. 